\title{
THE EFFECT OF TEMPERATURE AND PRECIPITATION CONDITIONS ON THE GROWTH AND DEVELOPMENT DYNAMICS OF FIVE CULTIVARS OF PROCESSING TOMATO
}

\author{
Elżbieta JĘDRSZCZYK ${ }^{1 *}$, Barbara SKOWERA ${ }^{2}$, Maria GAWĘDA ${ }^{1}$, Andrzej LIBIK $^{1}$ \\ ${ }^{1}$ University of Agriculture, Department of Vegetable and Medicinal Plants, \\ al. 29 Listopada 54, 31-425 Kraków, Poland \\ ${ }^{2}$ University of Agriculture, Department of Ecology, Climatology and Air Protection, \\ al. Mickiewicza 24/28, 30-059 Kraków, Poland
}

Received: December 2015; Accepted: March 2016

\begin{abstract}
Cultivation of field tomato in Poland meets unfavorable temperature and precipitation conditions, which affect yield and quality. The aim of the study is to evaluate the effect of temperature and precipitation conditions on the growth and development dynamics of five cultivars of processing tomato. The analysis took into account the key morphological characteristics of the plant, the inflorescence and fruit, which determine the suitability of the cultivar for processing. Analysis of the effect of meteorological elements on the stem development showed that stem length was most strongly influenced by precipitation - both total precipitation and frequency, rather than by temperature; the greater the rainfall, the more intensive stem elongation. High levels of precipitation limited gains in stem thickness. The number of flowers and fruits formed per inflorescence was negatively correlated with temperature. Excessive precipitation during the entire growing period led to formation of smaller fruits. The length and width of the fruit were negatively correlated with the frequency of precipitation in all stages, and with total precipitation during the period from planting to setting of the first fruits. A beneficial effect of temperature on the length and width of the fruit was noted during the entire growing period. The tomato fruit formed a thicker pericarp when precipitation was more frequent.
\end{abstract}

Key words: weather, plant height, stem thickness, fruits features, phases, correlations

\section{INTRODUCTION}

Tomatoes are one of the major vegetables grown in Poland and worldwide, and are continually gaining in importance. Their popularity requires a large supply of raw material to the market, both for the sale as fresh fruit and for processing. In Poland, the processing industry consumes 150,000 ton of field tomatoes annually, which is 40 to $60 \%$ of total production (Zalewska-Korona \& JabłońskaRyś 2012). Poland is the tenth among European potentates in tomato cultivation, so the demand for the vegetable is met by import from leading tomato-producing countries, mainly Spain and Italy (FAMMU/FAPA 2013).
Tomato plant development and yield are closely related to environmental factors, such as soil and climate conditions. Tomato grown in the field is sensitive to low temperatures, which limits its cultivation in terms of both geographical latitude and time of year (Kacjan-Maršić et al. 2005). Poland is the northernmost country where tomato can be grown in the field. Nevertheless, there are regions of Poland with highly favorable environmental and climatic conditions such as the Sandomierz Basin and regions of Lublin, Krakow and Lodz (Suszyna 2005; 2006).

Cultivation of field tomato in Poland meets with unfavorable temperature and precipitation conditions, which affects yield and quality. In a study 
conducted on indeterminate types of tomato, Dyduch et al. (2014) demonstrated that the profitability of production was most dependent on weather conditions (temperature and precipitation) during the growing period. The differences in yield between favorable and unfavorable weather conditions amounted to $81.7 \%$. Analyzing the plant's heat requirements, Skowera et al. (2014a) demonstrated that temperature conditions for growing tomatoes are becoming increasingly favorable in the context of climate warming. The authors observed a 0.3$0.4{ }^{\circ} \mathrm{C}$ increase in air temperature in April-August, which may have a beneficial effect on the yield of this thermophilic species. Jędrszczyk et al. (2012a) found that tomato grown in the vicinity of Krakow tolerated varied temperature conditions well, and the factor determining yield was precipitation. A study by Skowera et al. (2014a) showed that in the years 1971-1990, there was no month in the growing period in which precipitation was insufficient for tomato cultivation, but the problem concerned an excessive precipitation. From 1991 to 2013, an increase was observed in the frequency of wet months in which total precipitation exceeded the demands of tomato plant by at least one standard deviation. The temperature and precipitation conditions during field cultivation determine the growth and development dynamics of the tomato plants, thereby affecting fruit yield and quality. However, the strength of influencing of these factors is dependent on the growth phase of the plant when conditions are unfavorable (Weerkody et al. 1997; Jędrszczyk et al. 2012a; Skowera et al. 2014b), and this is strictly dependent on the traits of the cultivar. Success in cultivating field tomato in Poland concerns mostly early cultivars (Jędrszczyk et al. 2012a; b). Obtaining of data concerning genetic variation and connections between various climate factors and fruit yield and quality are fundamental for improvement in the techniques used in cultivating this species (Akindele et al. 2011). Every year, tomato breeding provides new cultivars, both for direct consumption and for processing. Usually, hybrid cultivars adapt better to environmental conditions and have greater yield potential (Todorov \& Pevicharova 2003).
The aim of the study was to evaluate the effect of temperature and precipitation conditions on the growth of five cultivars of processing tomato. The analysis took into account the key morphological characteristics of the plant, the inflorescence and fruit, which determine the suitability of the cultivar for processing.

\section{MATERIALS AND METHODS}

The experiment was carried out in the years 2009-2011 at the Experimental Station of Vegetable and Medicinal Plants Department in Mydlniki, near Krakow. Five cultivars of determinate tomato 'Rumba', 'Hubal', 'Sokal $\mathrm{F}_{1}$ ', 'Mieszko $\mathrm{F}_{1}$ ' and 'Polset $F_{1}$ ' - were included in the study. They were chosen on the basis of previous experiments due to optimal chemical composition of fruit and good yielding in South Poland meteorological conditions (Jędrszczyk et al. 2012a; Skowera et al. 2014b). Sixweek seedlings were planted at $80 \times 60 \mathrm{~cm}$ spacing at different times of each year, depending on weather conditions - 21.05.2009, 29.05.2010 and 16.05.2011. May 2010 was extremely wet $(302 \mathrm{~mm}$ of precipitation), which delayed planting when seedlings were 7 weeks old. The experiment was set up in a single-factor design in four replications (20 plants per cultivar per replication). Cultivation procedures recommended for field tomato were carried out during the growing period: mechanical weed management, watering and disease protection as needed, in accordance with commonly applied tomato protection procedure. During the vegetation period, the meteorological elements, that is, air temperature and precipitation total were monitored on the experimental plots. Air temperature was recorded by HOBO Data Loger sensors (produced by Onset Company Corporation, USA) at the standard level $2 \mathrm{~m}$, precipitation was measured by Hellmann rain gauge at the standard level $1 \mathrm{~m}$. For each successive developmental stage of the plants, meteorological characteristics, including effective temperature sum $\left(>0{ }^{\circ} \mathrm{C}\right)$, total precipitation and number of days with precipitation as well as the duration of the developmental stage were determined. Mean monthly air temperature and total precipitation during vegeta- 
tion period 2009-2011 was showed on the background of multi-year 1981-2010.

The growth parameters were evaluated by measuring plant height and stem thickness on three phases: at the beginning of the flowering (3.06.2009, 8.06.2010 and 8.06.2011) according to BBCH scale code 61 and 601 , at the beginning of the fruit-setting (1.07.2009, 8.07.2010 and 5.07.2011) according to BBCH scale code 71 and 701 and before fruit harvest (25.08.2009, 8.09.2010 and 30.08.2011) according to BBCH scale code 99 and 909 (Feller et al. 1995). The numbers of flowers and fruits in the inflorescence located in the middle part of the plant were determined on eight randomly selected plants from each replication. The fruit was harvested on 7.09.2009, 14.09.2010 and 30.08.2011. Acceleration of the date of harvest in 2011 was dictated by a forecasted drop in temperature and by intensive rainfall. After harvesting, measurements of the weight, length and width of the fruit and of pericarp thickness in 15 fruits from the marketable yield of each cultivar were made.

The normality of the distribution of the plant parameters was tested by the Shapiro-Wilk test. As all of the variables met the conditions for normal distribution, significance of differences between means was evaluated by analysis of variance with Fisher's LSD test, at $\alpha=0.05$. Spearman's rank correlation coefficients were calculated between stem length and thickness and the meteorological characteristics for each developmental stage of plant growth. Spearman's correlation coefficients were also calculated between the meteorological characteristics and the number of flowers and fruits per inflorescence and the characteristics of the fruit after harvest - weight, length, width and pericarp thickness. The computations were performed in Statistica 10.

\section{RESULTS}

The development of the plants of each cultivar was found to be determined by the temperature sum and the number of days with precipitation presented in Tables 1 and 2.

The growth dynamics of the tomato stem depended both on the cultivar and on the meteorological conditions in each year of the study. In all three years, the 'Rumba' cultivar developed most intensively in the first growth stage, attaining the greatest height of all the varieties $(39.4 \mathrm{~cm})$ only two weeks after the seedlings were planted (beginning of flowering) (Table 3), after which its vegetative development slowed down. The 'Sokal $\mathrm{F}_{1}$ ' and 'Mieszko $F_{1}$ ' cultivars were characterized by the most intensive stem growth at the time of the second measurement (the beginning of fruit setting), which means that they did not develop intensively until the flowering stage. In the 'Sokal $F_{1}$ ' cultivar, stem elongation was completed quickly, before beginning of fruit setting (Table 3) (on average for the 3 years, it attained a length of $66.2 \mathrm{~cm}$ ), while 'Mieszko $F_{1}$ ' continued to grow intensively up to harvest time and achieved the greatest plant height of all the cultivars $(78.3 \mathrm{~cm})$. In the Hubal cultivar, the most intensive gains in stem length began only halfway through the growing period.

Table 1. Mean monthly air temperature and total precipitation during vegetation period 2009-2011 on the background of multi-year 1981-2010

\begin{tabular}{ccccccc}
\hline Meteorological elements & Years & May & June & July & August & September \\
\hline & $1981-2010$ & 14.0 & 16.8 & 18.8 & 18.2 & 13.5 \\
Mean temperature $\left({ }^{\circ} \mathrm{C}\right)$ & 2009 & 13.5 & 16.0 & 19.9 & 18.7 & 15.1 \\
& 2010 & 12.8 & 17.5 & 20.7 & 18.4 & 12.1 \\
& 2011 & 12.7 & 17.6 & 20.9 & 18.8 & 12.4 \\
\hline \multirow{3}{*}{ Total precipitation $(\mathrm{mm})$} & $1981-2010$ & 81.0 & 87.0 & 88.0 & 77.0 & 63.0 \\
& 2009 & 97.8 & 140.2 & 82.6 & 53.1 & 35.0 \\
& 2010 & 299.0 & 135.1 & 105.2 & 127.5 & 116.3 \\
& 2011 & 223.0 & 122.0 & 110.4 & 138.2 & 92.4 \\
\hline
\end{tabular}




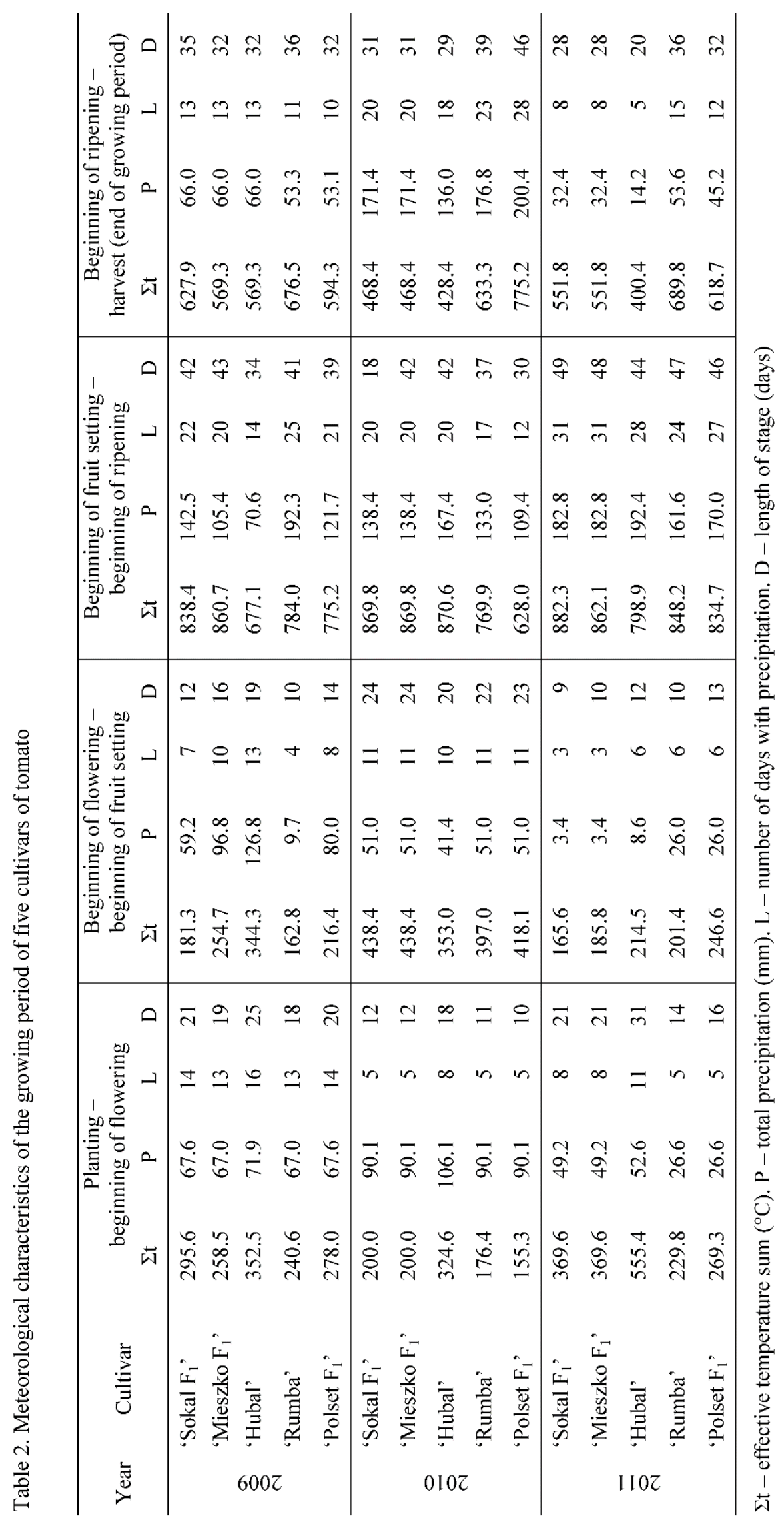


Table 3. Stem length in each tomato cultivar in successive developmental stages $(\mathrm{cm})$

\begin{tabular}{|c|c|c|c|c|c|}
\hline Stage & Cultivar & 2009 & 2010 & 2011 & Mean \\
\hline \multirow{6}{*}{$\begin{array}{l}\text { Beginning of } \\
\text { flowering }\end{array}$} & Sokal $F_{1}$ & $33.9 \mathrm{~cd}^{*}$ & $32.4 \mathrm{bc}$ & $46.4 \mathrm{f}$ & $37.6 \mathrm{C} * *$ \\
\hline & Mieszko $F_{1}$ & $30.8 \mathrm{~b}$ & $36.8 \mathrm{~d}$ & $42.0 \mathrm{e}$ & $36.6 \mathrm{BC}$ \\
\hline & Hubal & $26.7 \mathrm{a}$ & $33.8 \mathrm{c}$ & $25.6 \mathrm{a}$ & $28.7 \mathrm{~A}$ \\
\hline & Rumba & $33.0 \mathrm{bc}$ & $34.9 \mathrm{~cd}$ & $50.3 \mathrm{~g}$ & $39.4 \mathrm{D}$ \\
\hline & Polset $F_{1}$ & $24.3 \mathrm{a}$ & $35.1 \mathrm{~cd}$ & $46.6 \mathrm{f}$ & $35.3 \mathrm{~B}$ \\
\hline & Mean & $29.7 \mathrm{~A} * *$ & $34.6 \mathrm{~B}$ & $42.2 \mathrm{C}$ & \\
\hline \multirow{6}{*}{$\begin{array}{l}\text { Beginning of } \\
\text { fruit setting }\end{array}$} & Sokal $F_{1}$ & $57.3 \mathrm{~d}$ & $68.9 \mathrm{~g}$ & $65.1 \mathrm{fg}$ & $63.8 \mathrm{~B}$ \\
\hline & Mieszko $F_{1}$ & $54.8 \mathrm{bcd}$ & $77.3 \mathrm{~h}$ & $56.3 \mathrm{~d}$ & $62.8 \mathrm{~B}$ \\
\hline & Hubal & $50.0 \mathrm{ab}$ & $62.6 \mathrm{ef}$ & $59.2 \mathrm{de}$ & $57.3 \mathrm{~A}$ \\
\hline & Rumba & $50.8 \mathrm{abc}$ & 63.7 ef & $59.4 \mathrm{de}$ & $58.0 \mathrm{~A}$ \\
\hline & Polset $F_{1}$ & $49.8 \mathrm{a}$ & $67.3 \mathrm{fg}$ & $55.4 \mathrm{~cd}$ & $57.5 \mathrm{~A}$ \\
\hline & Mean & $52.5 \mathrm{~A}$ & $68.0 \mathrm{C}$ & $59.1 \mathrm{~B}$ & \\
\hline \multirow{6}{*}{ Harvest } & Sokal $F_{1}$ & $71.0 \mathrm{bcd}$ & $69.3 \mathrm{bc}$ & $58.4 \mathrm{a}$ & $66.2 \mathrm{~A}$ \\
\hline & Mieszko $\mathrm{F}_{1}$ & $80.6 \mathrm{de}$ & $88.1 \mathrm{e}$ & $66.0 \mathrm{ab}$ & $78.3 \mathrm{C}$ \\
\hline & Hubal & $74.5 \mathrm{bcd}$ & $76.9 \mathrm{~cd}$ & $73.5 \mathrm{bcd}$ & $75.0 \mathrm{BC}$ \\
\hline & Rumba & $70.8 \mathrm{bcd}$ & $65.8 \mathrm{ab}$ & $66.6 \mathrm{ab}$ & $67.7 \mathrm{~A}$ \\
\hline & Polset $F_{1}$ & $65.3 \mathrm{ab}$ & $79.6 \mathrm{de}$ & $67.6 \mathrm{abc}$ & $70.8 \mathrm{AB}$ \\
\hline & Mean & $72.4 \mathrm{~B}$ & $75.9 \mathrm{~B}$ & $66.4 \mathrm{~A}$ & \\
\hline
\end{tabular}

* Low letter - two-factor analyze (interaction). Differences designated by the same letter are statistically significant at $\alpha=0.05$ for each stage separately

** Capital letters in last column show the differences for cultivar factor in spite of the year. Capital letters in shadow rows show the differences between years

Table 4. Stem thickness of each tomato cultivar in successive developmental stages (mm)

\begin{tabular}{|c|c|c|c|c|c|}
\hline Stage & Cultivar & 2009 & 2010 & 2011 & Mean \\
\hline \multirow{6}{*}{$\begin{array}{l}\text { Beginning of } \\
\text { flowering }\end{array}$} & Sokal $F_{1}$ & $8.0 \mathrm{~d} *$ & $7.4 \mathrm{bc}$ & $10.6 \mathrm{f}$ & $8.7 \mathrm{~B} * *$ \\
\hline & Mieszko $F_{1}$ & $7.9 \mathrm{~cd}$ & $7.4 \mathrm{bc}$ & $10.7 \mathrm{f}$ & $8.7 \mathrm{~B}$ \\
\hline & Hubal & $9.1 \mathrm{e}$ & $6.4 \mathrm{a}$ & $7.6 \mathrm{bcd}$ & $7.7 \mathrm{~A}$ \\
\hline & Rumba & $8.9 \mathrm{e}$ & $7.2 \mathrm{~b}$ & $11.3 \mathrm{~g}$ & $9.1 \mathrm{C}$ \\
\hline & Polset $F_{1}$ & $8.9 \mathrm{e}$ & $8.0 \mathrm{~d}$ & $11.6 \mathrm{~g}$ & $9.5 \mathrm{D}$ \\
\hline & Mean & $8.6 \mathrm{~B} * *$ & $7.3 \mathrm{~A}$ & $10.4 \mathrm{C}$ & \\
\hline \multirow{6}{*}{$\begin{array}{l}\text { Beginning of } \\
\text { fruit setting }\end{array}$} & Sokal $F_{1}$ & $12.2 \mathrm{ab}$ & $13.3 \mathrm{bc}$ & 14.4 cde & $13.3 \mathrm{AB}$ \\
\hline & Mieszko $F_{1}$ & $13.8 \mathrm{~cd}$ & $14.1 \mathrm{~cd}$ & $15.6 \mathrm{f}$ & $14.5 \mathrm{C}$ \\
\hline & Hubal & $13.8 \mathrm{~cd}$ & $12.1 \mathrm{ab}$ & $14.9 \mathrm{def}$ & $13.6 \mathrm{~B}$ \\
\hline & Rumba & $12.3 \mathrm{ab}$ & $12.2 \mathrm{ab}$ & $15.5 \mathrm{ef}$ & $13.3 \mathrm{AB}$ \\
\hline & Polset $F_{1}$ & $11.6 \mathrm{a}$ & $12.2 \mathrm{ab}$ & $14.7 \mathrm{def}$ & $12.9 \mathrm{~A}$ \\
\hline & Mean & $12.7 \mathrm{~A}$ & $12.8 \mathrm{~A}$ & $15.0 \mathrm{~B}$ & \\
\hline \multirow{6}{*}{ Harvest } & Sokal $F_{1}$ & $14.7 \mathrm{~b}$ & $16.9 \mathrm{de}$ & $14.9 \mathrm{bc}$ & $15.5 \mathrm{AB}$ \\
\hline & Mieszko $F_{1}$ & $16.3 \mathrm{bcde}$ & $17.8 \mathrm{e}$ & $16.5 \mathrm{cde}$ & $16.9 \mathrm{C}$ \\
\hline & Hubal & $15.3 \mathrm{bcd}$ & $16.5 \mathrm{cde}$ & $15.9 \mathrm{bcd}$ & $15.9 \mathrm{~B}$ \\
\hline & Rumba & $15.3 \mathrm{bcd}$ & 16.3 bcde & $16.5 \mathrm{cde}$ & $16.1 \mathrm{BC}$ \\
\hline & Polset $F_{1}$ & $12.9 \mathrm{a}$ & $15.5 \mathrm{bcd}$ & $15.4 \mathrm{bcd}$ & $14.6 \mathrm{~A}$ \\
\hline & Mean & $14.9 \mathrm{~A}$ & $16.6 \mathrm{~B}$ & $15.9 \mathrm{~B}$ & \\
\hline
\end{tabular}

$*$, ** see Table 3 
At the beginning of the growing period, the Hubal cultivar had the thinnest stems in years 201011, which did not begin to grow thicker until the fruit-setting stage (Table 4). The Rumba and 'Polset $F_{1}$ ' cultivars were characterized by intensive gains in stem thickness from the very beginning; stem thickness growth was completed sooner in 'Polset $\mathrm{F}_{1}$ ', while the Rumba stem thickened intensely until the end of the growing period. The thickest stem at the time of the second and third measurements was noted in the 'Mieszko $F_{1}$ ' cultivar.

Analysis of the effect of meteorological conditions on the development dynamics of the tomato cultivars showed that in the first stage, from planting to the beginning of flowering, the plants gained in length and thickness most intensively in 2011, which was characterized by the highest temperature sums and the lowest precipitation totals (Tables 1$4)$. The slowest stem elongation growth was observed in 2009 when precipitation was most frequent but low, and the temperature sums were intermediate with respect to the other years. The plants had the thinnest stems in 2010, which had the highest precipitation totals in this phase.

From the beginning of flowering to fruit setting, the most intensive stem elongation was observed in 2010, when the temperature sums were the highest and least varied, and the distribution of precipitation was uniform. The plants grew most slowly in this stage in 2009 , when the precipitation totals ranged from 10 to $127 \mathrm{~mm}$ (Tables $2 \& 3$ ), and the duration of the stage ranged from 10 (Rumba) to 19 days (Hubal). In the second stage, the thickest stems were observed in 2011, when this stage was characterized by low precipitation levels and low frequency of precipitation (Tables $2 \& 4$ ).

At the end of the growing period the shortest plants, but with thick stems, were noted in 2011, when precipitation during this stage was lowest (14$45 \mathrm{~mm}$ ). In this stage, the tallest plants were observed in 2009 and 2010, but the thinnest stems were noted in 2009 (Tables 2-4).

Temperature did not influence stem growth, except for a positive correlation with temperature between beginning of fruit setting and harvest (Table 5). A precipitation total during first two stages was negatively correlated with stem thickness and number of days with rainfall during first two stages with the shoot length. Heavy precipitation during second and third stages correlated positively with stem length. The length of the second and third periods correlated negatively with shoot length and the length of the first period with the stem thickness at the first stage (Table 5).

The number of flowers and fruit set per inflorescence depended on both the cultivar and the year. The weather conditions in 2009, in comparison to the other years of the study, led to the formation of significantly more flowers and fruits per the inflorescence. The cultivars 'Sokal F $F_{1}$ ', 'Mieszko $F_{1}$ ' and Rumba had the highest number of flowers formed per inflorescence (8.2-9.5) and of fruit sets from them (5.0-6.0), as averaged for 3 years (Table 6).

The average fruit weight depended on the cultivar and year of cultivation. In each year, the smallest weight had fruit of 'Sokal $F_{1}$ ' and the greatest of 'Hubal'. The values ranged from 64.3-101.7 to 123.3-157.6 g, respectively. The length and width of fruit (shape) are genetically determined, but significant differences between years were noticed. The largest fruits were formed in 2011 and the smallest in 2010 (Table 6).

Also, the thickness of the fruit pericarp varied depending on the year and cultivar. The thickest pericarps were observed in 2009, and the thinnest in 2011. The thickest pericarp had fruit of 'Mieszko $F_{1}$ ' and the thinnest of 'Polset $F_{1}$ ' (Table 6).

The number of flowers and fruits formed per inflorescence was negatively correlated with temperature at the second stage period and the number of flowers also on temperature between fruit setting and harvesting. Apart from temperature, no other factors were found to affect the inflorescence characteristics (Table 7).

Frequency of rainfall through first and second development stage was negatively correlated with length and width of the fruit and precipitation frequency during the third stage of development. The weight of the fruit of the cultivars analyzed here depended only on temperature in the first stage (until the beginning of flowering), that is, when the plant was still in the vegetative stage of development (Table 7). Excessive precipitation during the third growing stage was negatively correlated with fruit weight. The tomato fruit formed a thicker pericarp when precipitation was more frequent during the first two stages of development (Table 7). 
Table 5. Spearman's rank correlation coefficients between tomato stem length and thickness and meteorological elements $(n=15)$

\begin{tabular}{|c|c|c|c|c|c|c|c|}
\hline \multirow{2}{*}{$\begin{array}{c}\text { Develop- } \\
\text { mental stage }\end{array}$} & \multirow{2}{*}{ Element } & \multicolumn{2}{|c|}{ Beginning of flowering } & \multicolumn{2}{|c|}{ Beginning of fruit setting } & \multicolumn{2}{|c|}{ End of growing period } \\
\hline & & length & thickness & length & thickness & length & thickness \\
\hline \multirow{4}{*}{$\begin{array}{l}\text { Planting - } \\
\text { beginning } \\
\text { of flowering }\end{array}$} & temperature sum & -0.19 & 0.30 & -0.42 & 0.28 & -0.21 & -0.39 \\
\hline & precipitation total & -0.35 & $-0.83 *$ & 0.40 & $-0.71 *$ & $0.61 *$ & 0.25 \\
\hline & $\begin{array}{l}\text { number of days with pre- } \\
\text { cipitation }\end{array}$ & $-0.68 *$ & 0.13 & $-0.75^{*}$ & -0.29 & 0.10 & $-0.68 *$ \\
\hline & length of period & -0.38 & 0.32 & $-0.56^{*}$ & 0.21 & -0.12 & $-0.55^{*}$ \\
\hline \multirow{4}{*}{$\begin{array}{l}\text { Planting - } \\
\text { beginning } \\
\text { of fruit set- } \\
\text { ting }\end{array}$} & temperature sum & & & 0.38 & 0.08 & 0.45 & 0.31 \\
\hline & precipitation total & & & -0.18 & $-0.59 *$ & $0.60 *$ & -0.01 \\
\hline & $\begin{array}{l}\text { number of days with pre- } \\
\text { cipitation }\end{array}$ & & & -0.50 & $-0.58 *$ & $0.54 *$ & -0.36 \\
\hline & length of period & & & 0.07 & -0.25 & $0.63 *$ & 0.12 \\
\hline \multirow{4}{*}{$\begin{array}{l}\text { Planting - } \\
\text { harvesting }\end{array}$} & temperature sum & & & & & 0.28 & $0.74 *$ \\
\hline & precipitation total & & & & & $0.64 *$ & 0.36 \\
\hline & $\begin{array}{l}\text { number of days with pre- } \\
\text { cipitation }\end{array}$ & & & & & $0.70 *$ & 0.20 \\
\hline & length of period & & & & & $0.61 *$ & -0.02 \\
\hline
\end{tabular}

Table 6. Inflorescence and fruit features in each tomato cultivar

\begin{tabular}{|c|c|c|c|c|c|}
\hline Feature & Cultivar & 2009 & 2010 & 2011 & Mean for cultivan \\
\hline \multirow{6}{*}{$\begin{array}{l}\text { Number of flowers } \\
\text { per inflorescence }\end{array}$} & Sokal F 1 & $11.3 \mathrm{~cd}^{*}$ & $8.1 \mathrm{abc}$ & $9.0 \mathrm{bcd}$ & $9.5 \mathrm{C}^{* *}$ \\
\hline & Mieszko $F_{1}$ & $8.0 \mathrm{abc}$ & $7.5 a b c$ & $9.1 \mathrm{bcd}$ & $8.2 \mathrm{BC}$ \\
\hline & Hubal & $6.8 \mathrm{ab}$ & $5.9 \mathrm{ab}$ & $5.1 \mathrm{a}$ & $5.9 \mathrm{~A}$ \\
\hline & Rumba & $12.3 \mathrm{~d}$ & $6.1 \mathrm{ab}$ & $6.8 \mathrm{ab}$ & $8.4 \mathrm{BC}$ \\
\hline & Polset $F_{1}$ & $7.0 \mathrm{ab}$ & $6.3 \mathrm{ab}$ & $7.4 \mathrm{ab}$ & $6.9 \mathrm{AB}$ \\
\hline & mean for year & $9.1 \mathrm{~B}^{* *}$ & $6.8 \mathrm{~A}$ & $7.5 \mathrm{AB}$ & \\
\hline \multirow{6}{*}{$\begin{array}{l}\text { Number of fruits } \\
\text { per inflorescence }\end{array}$} & Sokal $F_{1}$ & $7.3 \mathrm{de}$ & $5.3 \mathrm{abc}$ & $4.6 \mathrm{ab}$ & $5.7 \mathrm{C}$ \\
\hline & Mieszko $F_{1}$ & $6.8 \mathrm{cde}$ & 5.8 bcde & 5.4 abcd & $6.0 \mathrm{C}$ \\
\hline & Hubal & $3.8 \mathrm{a}$ & $3.8 \mathrm{a}$ & $3.9 \mathrm{ab}$ & $3.8 \mathrm{~A}$ \\
\hline & Rumba & $7.6 \mathrm{e}$ & $3.8 \mathrm{a}$ & $3.6 \mathrm{a}$ & $5.0 \mathrm{BC}$ \\
\hline & Polset $F_{1}$ & $5.1 \mathrm{abc}$ & $4.4 \mathrm{ab}$ & $4.0 \mathrm{ab}$ & $4.5 \mathrm{AB}$ \\
\hline & mean for year & $6.1 \mathrm{~B}$ & $4.6 \mathrm{~A}$ & $4.3 \mathrm{~A}$ & \\
\hline \multirow{6}{*}{$\begin{array}{l}\text { Average fruit } \\
\text { weight }(\mathrm{g})\end{array}$} & Sokal F 1 & $89.0 \mathrm{bc}$ & $64.3 \mathrm{a}$ & $101.7 \mathrm{bcd}$ & $85.0 \mathrm{~A}$ \\
\hline & Mieszko $F_{1}$ & $85.5 \mathrm{ab}$ & $83.8 \mathrm{ab}$ & $105.8 \mathrm{bcd}$ & $91.7 \mathrm{AB}$ \\
\hline & Hubal & $157.6 \mathrm{f}$ & $123.3 \mathrm{de}$ & $182.3 \mathrm{~g}$ & $154.4 \mathrm{D}$ \\
\hline & Rumba & $91.5 \mathrm{bc}$ & $90.9 \mathrm{bc}$ & $119.4 \mathrm{de}$ & $100.6 \mathrm{~B}$ \\
\hline & Polset $F_{1}$ & 141.9 ef & $110.9 \mathrm{~cd}$ & $150.9 \mathrm{f}$ & $134.6 \mathrm{C}$ \\
\hline & mean for year & $113.1 \mathrm{~B}$ & $94.6 \mathrm{~A}$ & $132.0 \mathrm{C}$ & \\
\hline \multirow{6}{*}{$\begin{array}{l}\text { Average fruit } \\
\text { length (mm) }\end{array}$} & Sokal $F_{1}$ & $54.1 \mathrm{~cd}$ & $53.6 \mathrm{~cd}$ & $60.4 \mathrm{fgh}$ & $56.0 \mathrm{BC}$ \\
\hline & Mieszko $F_{1}$ & $60.5 \mathrm{fgh}$ & $61.8 \mathrm{gh}$ & $63.5 \mathrm{~h}$ & $61.9 \mathrm{D}$ \\
\hline & Hubal & 57.9 ef & $54.4 \mathrm{~cd}$ & $59.3 \mathrm{fg}$ & $57.2 \mathrm{C}$ \\
\hline & Rumba & $48.7 \mathrm{a}$ & $47.7 \mathrm{a}$ & $52.3 \mathrm{bc}$ & $49.6 \mathrm{~A}$ \\
\hline & Polset $F_{1}$ & $58.2 \mathrm{ef}$ & $49.4 \mathrm{ab}$ & $56.0 \mathrm{de}$ & $54.6 \mathrm{~B}$ \\
\hline & mean for year & $55.9 \mathrm{~B}$ & $53.4 \mathrm{~A}$ & $58.3 \mathrm{C}$ & \\
\hline \multirow{6}{*}{$\begin{array}{l}\text { Average fruit width } \\
(\mathrm{mm})\end{array}$} & Sokal F $_{1}$ & $53.7 \mathrm{bcd}$ & $46.2 \mathrm{a}$ & $55.8 \mathrm{cde}$ & $51.9 \mathrm{~A}$ \\
\hline & Mieszko $F_{1}$ & 50.7 abc & $49.3 \mathrm{ab}$ & 54.8 bcde & $51.6 \mathrm{~A}$ \\
\hline & Hubal & $69.4 \mathrm{ij}$ & 64.5 ghi & $72.0 \mathrm{j}$ & $68.6 \mathrm{D}$ \\
\hline & Rumba & $57.5 \mathrm{de}$ & $57.8 \mathrm{def}$ & $63.5 \mathrm{fgh}$ & $59.6 \mathrm{~B}$ \\
\hline & Polset $F_{1}$ & $66.4 \mathrm{hij}$ & $59.9 \mathrm{efg}$ & $67.5 \mathrm{hij}$ & $64.6 \mathrm{C}$ \\
\hline & mean for year & $59.6 \mathrm{~B}$ & $55.5 \mathrm{~A}$ & $62.7 \mathrm{C}$ & \\
\hline \multirow{6}{*}{$\begin{array}{l}\text { Pericarp thickness } \\
(\mathrm{mm})\end{array}$} & Sokal F 1 & 5.9 cde & 6.6 efg & $5.3 \mathrm{bc}$ & $5.9 \mathrm{~B}$ \\
\hline & Mieszko $F_{1}$ & $7.3 \mathrm{fg}$ & $7.5 \mathrm{~g}$ & $6.5 \mathrm{ef}$ & $7.1 \mathrm{C}$ \\
\hline & Hubal & $6.7 \mathrm{efg}$ & $5.5 \mathrm{bcd}$ & $5.4 \mathrm{bc}$ & $5.8 \mathrm{~B}$ \\
\hline & Rumba & $6.1 \mathrm{cde}$ & $6.0 \mathrm{cde}$ & $4.6 \mathrm{ab}$ & $5.8 \mathrm{~B}$ \\
\hline & Polset $F_{1}$ & $6.3 \mathrm{def}$ & $4.2 \mathrm{a}$ & $4.0 \mathrm{a}$ & $4.8 \mathrm{~A}$ \\
\hline & mean for year & $6.4 \mathrm{C}$ & $6.0 \mathrm{~B}$ & $5.2 \mathrm{~A}$ & \\
\hline
\end{tabular}


Table 7. Spearman's rank correlation coefficients between inflorescence and fruit characteristics and meteorological elements $(n=15)$

\begin{tabular}{|c|c|c|c|c|c|c|c|}
\hline $\begin{array}{l}\text { Developmen- } \\
\text { tal stage }\end{array}$ & Element & $\begin{array}{c}\text { Number of } \\
\text { flowers } \\
\text { per inflo- } \\
\text { rescence }\end{array}$ & $\begin{array}{c}\text { Number of } \\
\text { fruits per } \\
\text { inflo- } \\
\text { rescence }\end{array}$ & $\begin{array}{c}\text { Fruit } \\
\text { weight } \\
\text { (g) }\end{array}$ & $\begin{array}{l}\text { Fruit } \\
\text { length } \\
(\mathrm{mm})\end{array}$ & $\begin{array}{l}\text { Fruit } \\
\text { width } \\
(\mathrm{mm})\end{array}$ & $\begin{array}{l}\text { Thickness } \\
\text { of periph- } \\
\text { eral walls } \\
\quad(\mathrm{mm})\end{array}$ \\
\hline \multirow{4}{*}{$\begin{array}{l}\text { Planting-be- } \\
\text { ginning of } \\
\text { flowering }\end{array}$} & temperature sum & 0.10 & -0.26 & $0.56 *$ & 0.15 & 0.09 & 0.21 \\
\hline & precipitation total & -0.21 & -0.06 & -0.35 & -0.30 & -0.27 & 0.16 \\
\hline & $\begin{array}{l}\text { number of days } \\
\text { with precipitation }\end{array}$ & 0.47 & 0.16 & 0.32 & $-0.60 *$ & $-0.60 *$ & $0.56^{*}$ \\
\hline & length of period & 0.26 & -0.10 & 0.50 & -0.07 & -0.15 & 0.39 \\
\hline \multirow{4}{*}{$\begin{array}{l}\text { Planting-be- } \\
\text { ginning of } \\
\text { fruit setting }\end{array}$} & temperature sum & $-0.61 *$ & $-0.57 *$ & 0.19 & 0.33 & 0.34 & 0.06 \\
\hline & precipitation total & -0.05 & -0.01 & -0.08 & $-0.57 *$ & $-0.56^{*}$ & 0.46 \\
\hline & $\begin{array}{l}\text { number of days } \\
\text { with precipitation }\end{array}$ & 0.13 & 0.11 & 0.13 & $-0.76^{*}$ & $-0.65^{*}$ & $0.53^{*}$ \\
\hline & length of period & -0.34 & -0.26 & 0.12 & -0.12 & -0.16 & 0.43 \\
\hline \multirow{4}{*}{$\begin{array}{l}\text { Planting - } \\
\text { harvest }\end{array}$} & temperature sum & $-0.62 *$ & -0.35 & -0.29 & $0.55^{*}$ & $0.53 *$ & -0.40 \\
\hline & precipitation total & -0.17 & 0.06 & $-0.52 *$ & -0.31 & -0.32 & 0.13 \\
\hline & $\begin{array}{l}\text { number of days } \\
\text { with precipitation }\end{array}$ & -0.03 & 0.12 & -0.48 & -0.49 & $-0.53^{*}$ & 0.29 \\
\hline & length of period & -0.17 & -0.20 & -0.04 & -0.20 & -0.22 & 0.20 \\
\hline
\end{tabular}

* Statistically significant correlation coefficients $(\alpha=0.05)$

\section{DISCUSSION}

The length of developmental stages and thus the dynamics of plant development are determined by temperature and precipitation conditions and by the genetic nature of the cultivar. Many authors emphasize the importance of the selection of cultivar for cultivation in specific environmental and climatic conditions (Akindele et al. 2011; Suszyna, 2005). Voican et al. (1995), in a study carried out in five regions of Romania, where the climate is warmer and drier than in Poland, found substantial variation in the rate of growth of tomato plants depending on the region, and thus on different temperature and precipitation conditions. The authors found the strongest positive correlation between the mean 10-day air temperature and plant growth in the regions with the highest temperatures and the lowest precipitation levels, and a weaker correlation in the remaining regions. In the present study, the stem length and thickness of plants of each cultivar varied substantially in years of the study, differing in temperature and precipitation conditions. The study found a statistically significant effect not only of the levels of precipitation, but also of its distribution in different developmental stages. In the climatic conditions of southern Poland, the most dynamic development in the first stages was noted in the Rumba, while the Hubal was characterized by the weakest development at the beginning of the growing period and strong development in the later stages. Information on the sensitivity of cultivars to weather conditions is very important for breeders of new cultivars and also for producers selecting cultivars to grow specifically for the sale of fresh fruit on the market or for processing. The processing industry, for example, requires that the cultivar has a thick, stiff stem with a short internode, because this allows the plant to remain in a vertical position for a long time, which is favorable to the health of the plant and fruit development (Jidavu et al. 2006).

A study on the effect of climate factors on the development of tomato plants from warm Mediterranean, subtropical and equatorial climates showed that a condition restricting the development of the tomato plant and thus fruit yield and quality, is high solar irradiance and in consequence, excessively high air temperature (Rajasekar et al. 2013; Akindele et al. 2011; Weerakkody et al. 1999; Weerakkody \& Peiris, 1998; Voican et al. 1995). 
A study conducted in temperate, transitional climatic conditions found that the level of precipitation and its frequency determine the development of the plant as well as yield and quality (Skowera et al. 2014b; Jędrszczyk et al. 2012a). The results obtained in the present study pertaining to the growth and development dynamics of five cultivars of processing tomato also confirmed that the effect of precipitation conditions is more significant than that of temperature conditions.

Weerakkody et al. (1997) showed that in warm, equatorial climate conditions, rainfall in the early flowering stage had a positive effect on fruit yield and quality, while precipitation during full flowering and fruit ripening reduced the weight of the fruit and the number of fruits per plant. In our study, conducted in cooler, temperate climate conditions, no relationship was found between meteorological elements and the number of flowers and fruits per inflorescence in the first stage (early flowering). However, taking into account longer periods from planting to full flowering and the entire growing period, we observed that the most important factor negatively correlated with the number of flowers and fruits per inflorescence was air temperature, while precipitation had no significant effect on these features.

The correlation coefficients obtained showed that the weight of the fruit was positively affected by air temperature as early as the first developmental stage of the plant (from planting to the beginning of flowering), and negatively affected by total precipitation during the last growing period. The length and width of the fruit were positively correlated with the temperature sum during the last growing period, and negatively with precipitation characteristics (total precipitation and number of days with precipitation) during the first two stages of growth. Pericarp thickness increased in proportion to the level of precipitation.

The study showed that in the environmental and climatic conditions of southern Poland, typically characterized by strong variation in temperature and precipitation conditions, the 'Mieszko $\mathrm{F}_{1}$ ' cultivar had the most useful fruit parameters for processing. Its fruits are smaller, with an elongated shape that is beneficial in processing a thick pericarp and a small number of chambers. Moreover, this cultivar was characterized by a thick, suitably long stem and a large number of flowers and fruits per inflorescence. The 'Sokal $F_{1}$ ' cultivar had similar inflorescence and fruit parameters, but formed fruits with a thinner pericarp. Unfortunately, the plants of this cultivar had thin stems, which, in conditions of high levels of precipitation, make it unsuitable for large-scale production.

To sum up, in the climatic conditions of southern Poland, the meteorological element determining the growth and development dynamics of the tomato is atmospheric precipitation, while the influence of temperature has a secondary role.

The selection of a suitable cultivar for specific environmental and climatic conditions is of great significance for production of processing tomatoes.

\section{Acknowledgements}

Research supported by the Ministry of Science and Higher Education of Poland: Number BZ 662/KWzEO/011, n/o of contract 1/04379/C.ZR 7-6/ZAŻ/ZO/2009.

\section{REFERENCES}

Akindele A.J., Ogunniyan D.J., Ajayi E.O. 2011. Phenotypic relationship among agronomic characters of commercial tomato (Lycopersicum esculentum) hybrids. American-Eurasian Journal of Agronomy 4 (1): 17-22.

Dyduch J., Suszyna J., Sałata A. 2014. Bio-productivity of two cultivars of indeterminate tomato plants in the field expressed in the size and structure of the fruit yield. Electronic Journal of Polish Agricultural Universities. Horticulture 17(2): \#03. http://www.ejpau.media.pl/vol.17/issue2/art03.html (26.04.2015)

FAMMU/FAPA 2013. According to Eurostat news release. (http://e-warzywnictwo.pl/wp-content/uploads/2013/10/no1343ow.pdf)

Feller C., Bleiholder H., Buhr L, Hack H., Hess M., Klose R. et al. 1995. Phänologische Entwicklungsstadien von Gemüsepflanzen: II. Fruchtgemüse und Hülsenfrüchte. Nachrichtenbl. Deut. Pflanzenschutzd. 47: 217-232. [in German]

Jędrszczyk E., Skowera B., Kopcińska J., Ambroszczyk A.M. 2012a. The influence of weather conditions during vegetation period on yielding of twelve determinate tomato cultivars. Notulae Botanicae 
Horti Agrobotanici Cluj-Napoca 40(2): 203-209. DOI: $10.15835 / \mathrm{nbha} 4028252$.

Jędrszczyk E., Ambroszczyk A.M., Kopcińska J., Skowera B., Sękara A. 2012b. Comparison of morphological characteristics of twelve cultivars of tomato determinate plants and their impact on yield and its structure. Vegetable Crops Research Bulletin 76: 89-97. DOI: 10.2478/v10032-0120006-1.

Jidavu M., Sestraş R., Apahidean M., Sestraş A., Hărşan E., Tămaş E., Gao Y. 2006. The response of several tomato cultivars for processing in central Transylvania conditions. I. Yield capacity. Notulae Botanicae Horti Agrobotanici Cluj-Napoca 34: $54-$ 61. DOI: $10.15835 /$ nbha341272.

Kacjan-Maršić N., Osvald J., Jakše M. 2005. Evaluation of ten cultivars of determinate tomato (Lycopersicum esculentum Mill.), grown under different climatic conditions. Acta Agriculturae Slovenica 85(2): 321-328.

Rajasekar M., Arumugam T., Ramesh Kumar S. 2013. Influence of weather and growing environment on vegetable growth and field. Journal of Horticulture and Forestry 5(10): 160-167. DOI: 10.5897/JHF2013.0317.

Skowera B., Szumlańska M., Jędrszczyk E. 2014a. Pluvio-thermal conditions in south part of KrakowskoCzęstochowska Upland influencing the risk of tomato field cultivation. Acta Agrophysica 21(3): 337-349. [in Polish with English abstract]

Skowera B., Jędrszczyk E., Kopcińska J., Ambroszczyk A.M., Kołton A. 2014b. The effects of hydrothermal conditions during vegetation period on fruit quality of processing tomatoes. Polish of Journal Environmental Studies 23(1): 195-202.
Suszyna J. 2005. Climatic conditions for cultivation of field tomato in the Sandomierz region. Acta Agrophysica 6(1): 237-249. [in Polish with English abstract]

Suszyna J. 2006. Influence of extreme moisture conditions on yielding of tomato in field cultivation. Folia Horticulturae Supplement 2: 181-185. [in Polish with English abstract]

Todorov T., Pevicharova G. 2003. Agrobiological and chemical evaluation of foreign determinate tomato cultivars. Rastenievudni Nauki 40(5): 457-461.

Voican V., Lãcãtuş V., Tãnãsescu M. 1995. Growth and development of tomato plants related to climatic conditions from some areas of Romania. Acta Horticulturae 412: 355-365. DOI: 10.17660/ActaHortic.1995.412.42.

Weerakkody W.A.P., Peiris B.C.N. 1998. Plant growth, flowering and fruit formation of tomato grown under protected culture. Tropical Agricultural Research 10: 236-245.

Weerakkody W.A.P., Peiris B.C.N., Jayasekara S.J.B.A. 1997. Yield and quality of tomato as affected by rainfall during different growth stages. Tropical Agricultural Research 9: 158-166.

Weerakkody W.A.P., Peiris B.C.N., Karunananda P.H., 1999. Fruit formation, marketable yield and fruit quality of tomato varieties grown under protected culture in two agro-ecological zones during the rainy season. Journal of the National Science Foundation of Sri Lanka 27(3): 177-186. DOI: 10.4038/jnsfsr.v27i3.3058.

Zalewska-Korona M., Jabłońska-Ryś E. 2012. Evaluation of processing usefulness of selected fruits of ground tomato cultivars. Żywność, Nauka, Technologia, Jakość 2(81): 77-87. [in Polish with English abstract] 